\title{
IMPLEMENTATION OF DATA MINING TO DETERMINE THE ASSOCIATION BETWEEN BODY CATEGORY FACTORS BASED ON BODY MASS INDEX
}

\author{
Desti Fitriati' ${ }^{1}$ Bima Putra Amiga ${ }^{2}$ \\ Program Studi Teknik Informatika ${ }^{1,2}$ \\ Universitas Pancasila ${ }^{1,2}$ \\ desti.fitriati@univpancasila.ac.id ${ }^{1}$, bimaamg@gmail.com²
}

\begin{abstract}
Abstrak
Perkembangan arus globalisasi yang semakin meningkat dalam bidang ilmu pengetahuan dan teknologi serta peningkatan pendapatan telah memberikan dampak pada berkurangnya aktivitas fisik masyarakat yang mengakibatkan penyimpangan pola makan dan aktivitas fisik yang membuat seseorang tidak memperhatikan bentuk tubuhnya. Metode perhitungan Indeks Massa Tubuh ini dapat digunakan untuk menentukan bentuk tubuh seseorang. Terdapat beberapa faktor yang dapat mempengaruhi nilai Indeks Massa Tubuh diantaranya adalah faktor individu, pola konsumsi, dan kurangnya aktivitas fisik yang mengarah pada pola hidup sedentaris (sedentary lifestyle). Faktor-faktor tersebut dijadikan menjadi 69 itemset yang akan dijadikan dasar pertanyaan dalam kuesioner untuk mengumpulkan dataset yang nantinya akan diolah menggunakan algoritma FP-Growth dan dicari aturan asosiasi yang memiliki nilai support $x$ confidence tertinggi. Dari 490 data hasil perhitungan dikategorikan menjadi 10 masing-masing adalah Laki-Laki dengan Indeks Massa Tubuh (IMT) Sangat Kurus dengan nilai support x confidence tertinggi sebesar 39,56\%, Laki-Laki dengan IMT Kurus sebesar 55,90\%, Laki-Laki dengan IMT Normal sebesar 70\%, Laki-Laki dengan IMT Gemuk sebesar 49,23\%, Laki-Laki dengan IMT Obesitas sebesar 41,34\%, Perempuan dengan IMT Sangat Kurus sebesar 41,37\%, Perempuan dengan IMT Kurus sebesar 37,21\%, Perempuan dengan IMT Normal sebesar 68,83\%, Perempuan dengan IMT Gemuk sebesar 41,65\%, dan Perempuan dengan IMT Obesitas sebesar 42,91\%.
\end{abstract}

Kata kunci: Algoritma FP-Growth, Data Mining, Asosiasi, Indeks Massa Tubuh, IMT

\begin{abstract}
The development of the increasing flow of globalization in the field of science and technology as well as increased income has resulted in reduced physical activity of the community which results in diverging diet and physical activity which makes a person not pay attention to his body shape. This method of calculating the Body Mass Index can be used to determine a person's body shape. Several factors can affect the value of the Body Mass Index, including individual factors, consumption patterns, and lack of physical activity which leads to a sedentary lifestyle. These factors are made into 69 itemsets which will be used as the basis for questions in the questionnaire to collect a dataset that will later be processed using the FP Growth algorithm and looking for association rules that have the highest support $\mathrm{x}$ confidence value. From the 490 calculation data, the results are categorized into 10, each of which is Men with a Very Thin BMI with the highest support $\mathrm{x}$ confidence value of $39.56 \%$, Men with a Thin BMI of $55.90 \%$, Men with a Normal BMI of $70 \%$, men with a fat BMI of $49.23 \%$, men with an obese BMI of $41.34 \%$, women with a very thin BMI of $41.37 \%$, women with a thin BMI of $37.21 \%$, Normal BMI is $68.83 \%$, women with obese BMI are $41.65 \%$, and women with obese BMI are $42.91 \%$.
\end{abstract}

Keywords: FP-Growth Algorithm, Data Mining, Associations, Body Mass Index, IMT

\section{PENDAHULUAN}

The development of the increasing flow of globalization in the field of science and technology as well as increasing incomes have had an impact on changes in lifestyle, behavior, and situations in the community (Ayuni, Suharso, \& Sukidin, 2019).
These changes have an impact on reduced physical activity (Suryadinata \& Sukarno, 2019) a society which results in divergent eating patterns and physical activities that make a person not pay attention to his body shape (Rahmayanti, 2016)

Some people feel their body is fat when in fact they are not fat or vice versa (Ariati, Gumala, \& 
Nursanyoto, 2017). This perception arises because a person does not know how to categorize his body shape (Nahdiyah, 2015) in the right way. One way to find out a person's body shape is by calculating the Body Mass Index method.

This method of calculating the Body Mass Index can be used to determine a person's nutritional status (Kusuma \& Pinandita, 2011), (Syahputra \& Muhathir, 2018). The results of the calculation of the Body Mass Index can be categorized into very thin, skinny, normal, overweight, and obese body shapes. (Putra \& Solichathi Rizqi, 2018). Among the Body Mass Index categories, obesity is a problem (Dewi \& Mahmudiono, 2013) where people who are categorized by body shape have excess nutrition (Dewi \& Mahmudiono, 2013). In public life, the term obesity is usually called overweight. This obesity phenomenon is the result of an unbalanced excessive intake of nutrients (Mahdali, 2019) by expending energy and can cause health problems (Hasanah \& Febrianti, 2012). A high Body Mass Index (BMI) value is indicated by a bodyweight above the average due to the accumulation of excess fat in the body over a long period. (Jannah \& Utami, 2018)

In 2016, WHO stated that the prevalence of obesity in the world has more than doubled since 1980 . In 2014, more than 1.9 billion adults aged 18 years and older were overweight, and 600 million among them are obese. Some of the factors associated with high Body Mass Index include high dietary habits and lack of physical activity which leads to a sedentary lifestyle such as watching television and playing computer/video games.

This study aims to examine the relationship between the factors that influence body shape based on a person's BMI which includes individual factors, physical activity, eating habits, sedentary behavior, and stress factors at work using the FPGrowth algorithm data mining method. Also, this study provides guidelines and guidelines to determine what factors influence body shape based on BMI.

\section{RESEARCH METHODS}

\section{Types of research}

This research is a type of experimental quantitative research, where the conclusion of this study is based on the results of the calculation trial which is selected the best.

\section{Time and Place of Research}

The data collection time in this study was October 2019.

\section{Research Target / Subject}

In this study using non-physical data by distributing questionnaires that have been compiled based on the results of a literature study. Then the questionnaire was distributed to general people using Google Form. The completed questionnaires will be collected in a file with the XLS extension. Subjects were taken randomly to get various types of body categories.

\section{Procedure}

The FP-Growth algorithm uses the concept of building a tree, which is commonly called the FPTree, in searching for Frequent itemsets instead of generating candidates as is done in the Apriori Algorithm. By using this concept, the FP-Growth algorithm is faster than the Apriori algorithm (Anggraeni, Iha, Erawati, \& Khairunnas, 2019). The following are the steps for the FP-Growth algorithm.

1. Determine the minimum support and minimum confidence.

2. Create an Fp-Tree based on the sorted itemset. Fp-Tree is formed by a root labeled Null, a group of trees whose members are certain items. Each node in the Fp-Tree contains three important information, namely the item label, informing the type of item the node represents, support count, representing the number of transaction paths that go through the node, and a pointer (Muliono, 2017).

3. Create a Conditional Pattern Base. Conditional Pattern Base is a sub-database that contains a prefix path and a pattern suffix. Generating the Conditional Pattern Base is obtained through the previously built Fp-Tree. The Conditional Pattern Base is obtained from the FP-tree.

4. Create a Conditional Fptree. At this stage, the support count of each item in each Conditional Pattern Base is added up, then each item that has a support count greater than the minimum support count will be generated with a conditional FP-tree. The conditional Fp.tree was obtained from the established fp.tree (Lestari, 2015).

5. Create a Frequent Pattern. The Frequent itemset Search Stage If the Conditional Fp-Tree is a single path, then the Frequent itemset is obtained by doing a combination of items for each conditional FP-tree. If it is not a single track, a Frequent Pattern will be generated. Frequent Patterns are obtained from the Conditional Fp-Tree

6. Create association rules. The results of the Association Rules are obtained from the conditional Frequent pattern which is entered 
into the support, confidence, lift ratio formula. Lift ratio is an important parameter besides support and confidence in the association rule. The lift ratio measures how important the rule is based on the value of support and confidence. The lift ratio is a value that indicates the validity of the transaction process and provides information on whether product $A$ has a relationship with product $B$. If the calculation results are looking for lift ratio $>1$, then we can determine a valid rule. The results of the Association Rules are obtained from the conditional Frequent pattern. And to find out the validation of the results of the association rules, the Support, Confidence, and Lift ratio values can be calculated.

Data, Instruments, and Data Collection Techniques

The data used in this study are primary, that is, the data is taken and processed by the researcher. The data collection technique used was a randomly distributed questionnaire form, where the instrument used was the Google Form.

\section{Data analysis technique}

The results of data processing using the FP Growth algorithm by setting a minimum support value which is determined based on the upper quartile calculation of the itemset frequency of each gender and BMI, and minimum confidence of $80 \%$. Where the minimum $80 \%$ confidence indicates the certainty that the data will appear in the item set.

\section{RESULTS AND DISCUSSION}

The results of the research are presented in graphical, tabular, or descriptive form. Analysis and interpretation of these results are required before the discussion.

\section{Data processing}

The data that will be used to predict this is obtained based on the results of the questionnaire that the respondents have filled in. The results of the questionnaire can be divided into 10 types of respondent characteristics based on gender and BMI category. The following is the distribution in Table 1 below.

Table 1. Data Grouping by Gender and BMI

\begin{tabular}{ccc}
\hline No. & Gender & BMI \\
\hline 1 & Laki- Laki & Sangat Kurus \\
2 & Laki- Laki & Kurus \\
3 & Laki- Laki & Normal
\end{tabular}

\begin{tabular}{ccc}
\hline No. & Gender & BMI \\
\hline 4 & Laki- Laki & Gemuk \\
5 & Laki- Laki & Obesitas \\
6 & Perempuan & Sangat Kurus \\
7 & Perempuan & Kurus \\
8 & Perempuan & Normal \\
9 & Perempuan & Gemuk \\
\hline
\end{tabular}

For the itemset used, there were 69 itemsets, among others, as shown in Table 2 below.

Table 2. List of Itemset Categories

\begin{tabular}{|c|c|c|}
\hline No. & Code & Itemset \\
\hline 1 & A1 & Remaja \\
\hline 2 & $\mathrm{~A} 2$ & Dewasa \\
\hline 3 & B1 & Jawa dan Bali \\
\hline 4 & B2 & Sumatra \\
\hline 5 & B3 & Kalimantan \\
\hline 6 & B4 & Papua \\
\hline 7 & B5 & Sulawesi \\
\hline 8 & B6 & Maluku \\
\hline 9 & B7 & Nusa Tenggara \\
\hline 10 & B8 & Pendatang \\
\hline 11 & $\mathrm{C} 1$ & Tidak Berpendidikan \\
\hline 12 & $\mathrm{C} 2$ & $\begin{array}{l}\text { Pendidikan Terakhir SD atau yang } \\
\text { Sederajat }\end{array}$ \\
\hline 13 & C3 & $\begin{array}{l}\text { Pendidikan Terakhir SMP atau yang } \\
\text { Sederajat }\end{array}$ \\
\hline 14 & $\mathrm{C} 4$ & $\begin{array}{l}\text { Pendidikan Terakhir SMA atau yang } \\
\text { Sederajat }\end{array}$ \\
\hline 15 & C5 & Pendidikan Terakhir D3 \\
\hline 16 & $\mathrm{C} 6$ & Pendidikan Terakhir D4 \\
\hline 17 & $\mathrm{C} 7$ & Pendidikan Terakhir S1 \\
\hline 18 & $\mathrm{C} 8$ & Pendidikan Terakhir S2 \\
\hline 19 & C9 & Pendidikan Terakhir S3 \\
\hline 20 & D1 & Perokok Aktif \\
\hline 21 & D2 & Perokok Pasif \\
\hline 22 & D3 & Mantan Perokok \\
\hline 23 & D4 & Tidak Rokok \\
\hline 24 & E1 & Waktu Tidur Ideal \\
\hline 25 & E2 & Waktu Tidur Tidak Ideal \\
\hline 26 & $\mathrm{~F} 1$ & Makan Pagi Sering \\
\hline 27 & F2 & Makan Pagi Sebagian Besar Waktu \\
\hline 28 & F3 & Makan Pagi Jarang \\
\hline 29 & F4 & Makan Pagi Tidak Pernah \\
\hline 30 & G1 & Makan Siang Sering \\
\hline 31 & G2 & Makan Siang Sebagian Besar Waktu \\
\hline 32 & G3 & Makan Siang Jarang \\
\hline 33 & G4 & Makan Siang Tidak Pernah \\
\hline 34 & $\mathrm{H} 1$ & Makan Malam Sering \\
\hline 35 & $\mathrm{H} 2$ & Makan Malam Sebagian Besar Waktu \\
\hline 36 & H3 & Makan Malam Jarang \\
\hline 37 & $\mathrm{H} 4$ & Makan Malam Tidak Pernah \\
\hline 38 & I1 & Konsumsi Susu Sering \\
\hline 39 & $\mathrm{I} 2$ & $\begin{array}{l}\text { Konsumsi Susu Sebagian Besar } \\
\text { Waktu }\end{array}$ \\
\hline 40 & I3 & Konsumsi Susu Jarang \\
\hline 41 & $\mathrm{I} 4$ & Konsumsi Susu Tidak Pernah \\
\hline 42 & J1 & Konsumsi Buah Sering \\
\hline 43 & $\mathrm{~J} 2$ & $\begin{array}{l}\text { Konsumsi Buah Sebagian Besar } \\
\text { Waktu }\end{array}$ \\
\hline 44 & $\mathrm{~J} 3$ & Konsumsi Buah Jarang \\
\hline
\end{tabular}




\begin{tabular}{|c|c|c|}
\hline No. & Code & Itemset \\
\hline 45 & $\mathrm{~J} 4$ & Konsumsi Buah Tidak Pernah \\
\hline 46 & K1 & Konsumsi Fast Food Sering \\
\hline 47 & K2 & $\begin{array}{l}\text { Konsumsi Fast Food Sebagian Besar } \\
\text { Waktu }\end{array}$ \\
\hline 48 & K3 & Konsumsi Fast Food Jarang \\
\hline 49 & K4 & Konsumsi Fas Food Tidak Pernah \\
\hline 50 & L1 & Konsumsi Makanan Kecil Sering \\
\hline 51 & L2 & $\begin{array}{l}\text { Konsumsi Makanan Kecil Sebagian } \\
\text { Besar Waktu }\end{array}$ \\
\hline 52 & L3 & Konsumsi Makanan Kecil Jarang \\
\hline 53 & L4 & $\begin{array}{l}\text { Konsumsi Makanan Kecil Tidak } \\
\text { Pernah }\end{array}$ \\
\hline 54 & M1 & Konsumsi Minuman Berasa Sering \\
\hline 55 & M2 & $\begin{array}{l}\text { Konsumsi Minuman Berasa Sebagian } \\
\text { Besar Waktu }\end{array}$ \\
\hline 56 & M3 & Konsumsi Minuman Berasa Jarang \\
\hline 57 & M4 & $\begin{array}{l}\text { Konsumsi Minuman Berasa Tidak } \\
\text { Pernah }\end{array}$ \\
\hline 58 & N1 & Konsumsi Soft Drink Sering \\
\hline 59 & N2 & $\begin{array}{l}\text { Konsumsi Soft Drink Sebagian Besar } \\
\text { Waktu }\end{array}$ \\
\hline 60 & N3 & Konsumsi Soft Drink Jarang \\
\hline 61 & $\mathrm{~N} 4$ & Konsumsi Soft Drink Tidak Pernah \\
\hline 62 & 01 & Sedentary Behavior Rendah \\
\hline 63 & 02 & Sedentary Behavior Tinggi \\
\hline 64 & P1 & Aktivitas Fisik Ringan \\
\hline 65 & $\mathrm{P} 2$ & Aktivitas Fisik Kuat \\
\hline 66 & P3 & Aktivitas Fisik Sedang \\
\hline 67 & Q1 & Stress Ringan \\
\hline 68 & Q2 & Stress Sedang \\
\hline 69 & Q3 & Stress Berat \\
\hline
\end{tabular}

\section{System Design}

The architecture of this system contains four kinds of data which can be seen in Figure 1, namely Login, category management, management dataset, and calculation of FP Growth. This login process is only done by the admin. Admin is required to log in before entering the system. The admin in this system is only one condition and cannot be added so that it does not require user management.

There are two data management systems for this system, namely the management data category and the management dataset. Categorical data that contains factors that affect the value of the Body Mass Index. While the dataset contains data from the distribution of questionnaires filled out by respondents.

Finally, the calculation of FP Growth, which contains the process of calculating FPGrowth from the tb_relation data, which contains data from the results of the respondent's questionnaire and is related to tb_data and tb_category. The calculation of FP-Growth is carried out to see the results of the association between the factors that affect the Body Mass Index value.

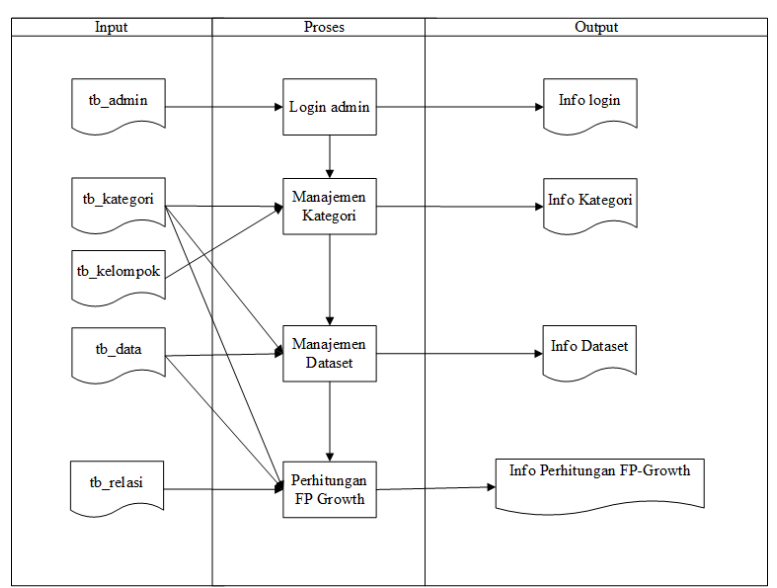

Figure 1. Software Architecture

The following is a snippet of the FP-Growth program:

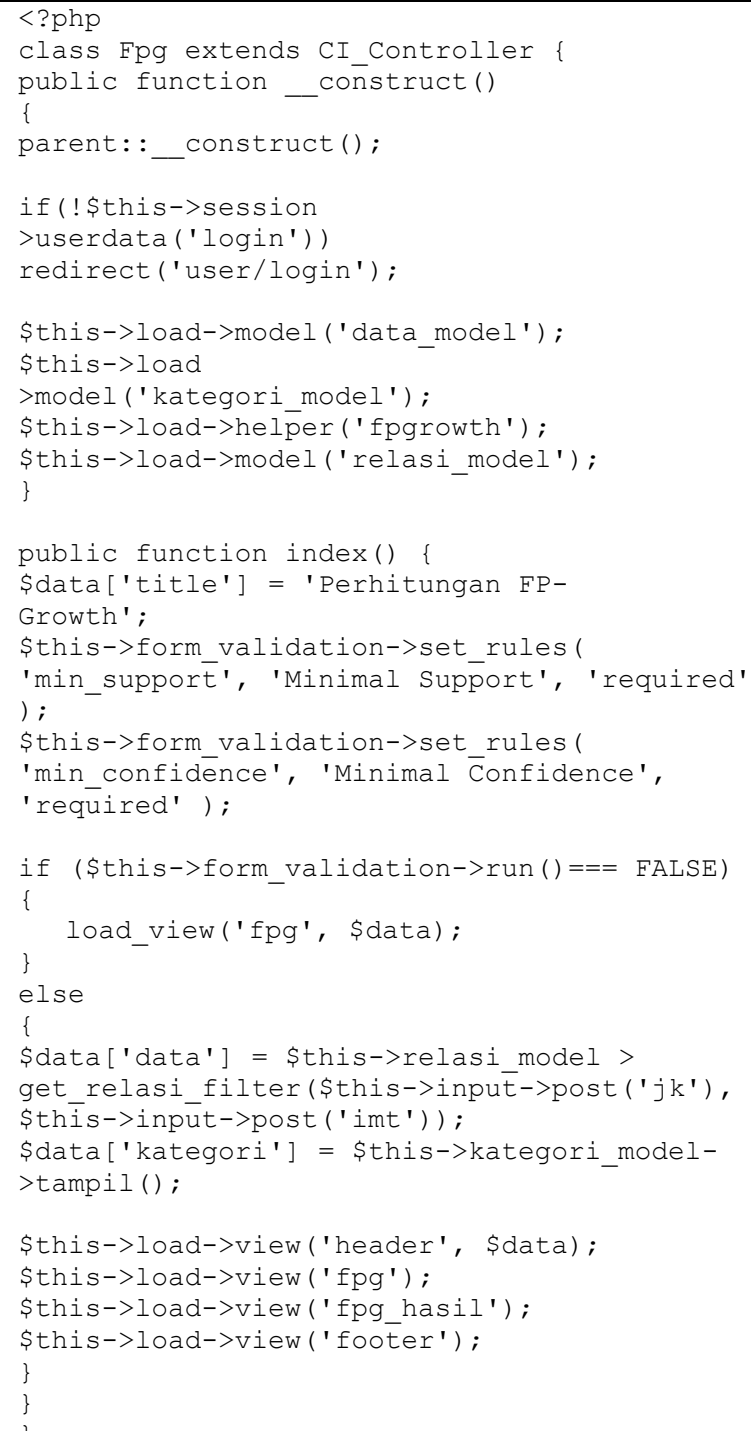




\section{Implementation Program}

1. FP-Growth Calculation page

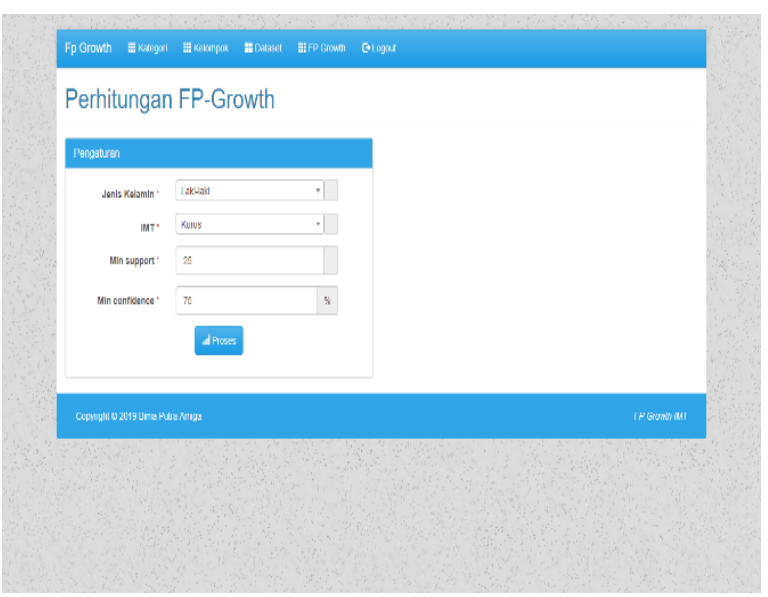

Figure 2. FP-Growth Calculation Page Interface

Figure 2 is the initial entry before calculating the FP Growth according to the selected category, where the entries include setting Gender, BMI Category, the minimum value of support, and minimum confidence. In this study, we will look for the associated value of the factors that affect the value of BMI based on gender and BMI category.

2. The interface of FP-Growth for Ordered Itemset Stage

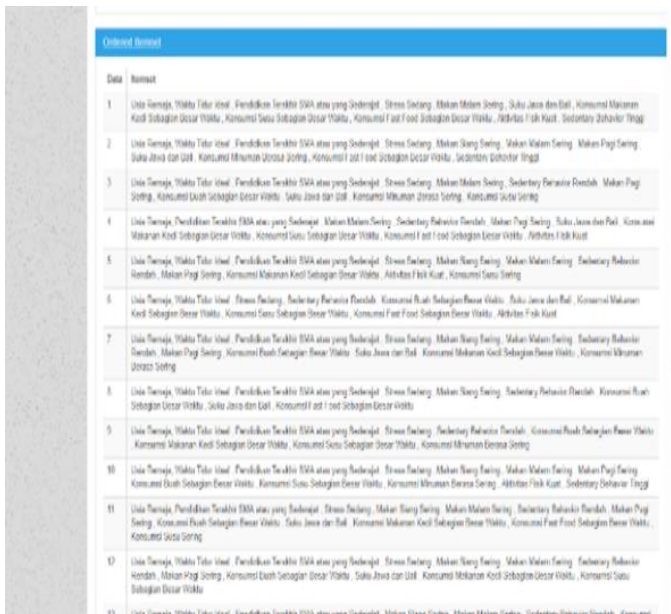

Figure 3 Detailed Interface Implementation

After making the initial settings, then the item combination process is carried out as seen in Figure 3 above.

3. FP-Growth Calculation Interface for Conditional FP-Tree Stage

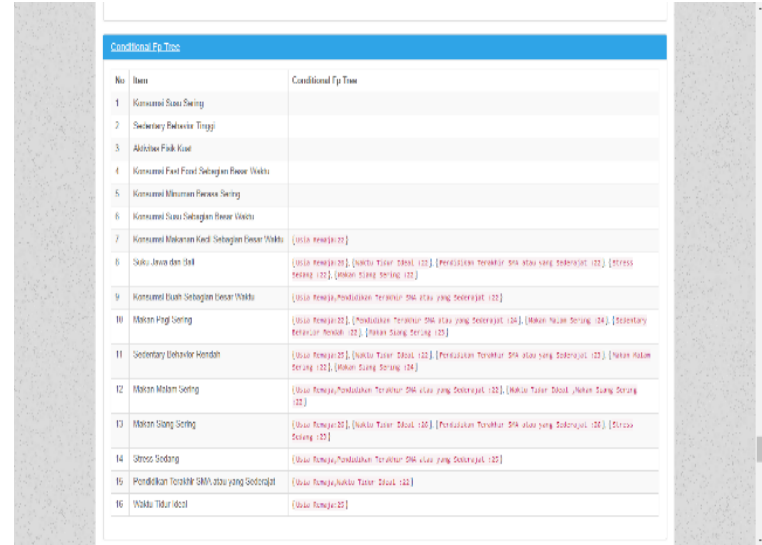

Figure 4 FP-Growth Calculation Interface for Conditional FP-Tree Stage

After obtaining an ordered itemset, the next step is to calculate the conditional pattern base and conditional FP-Tree to get the rules as shown in Figure 4 .

4. FP-Growth Calculation Interface Frequency Pattern Stage

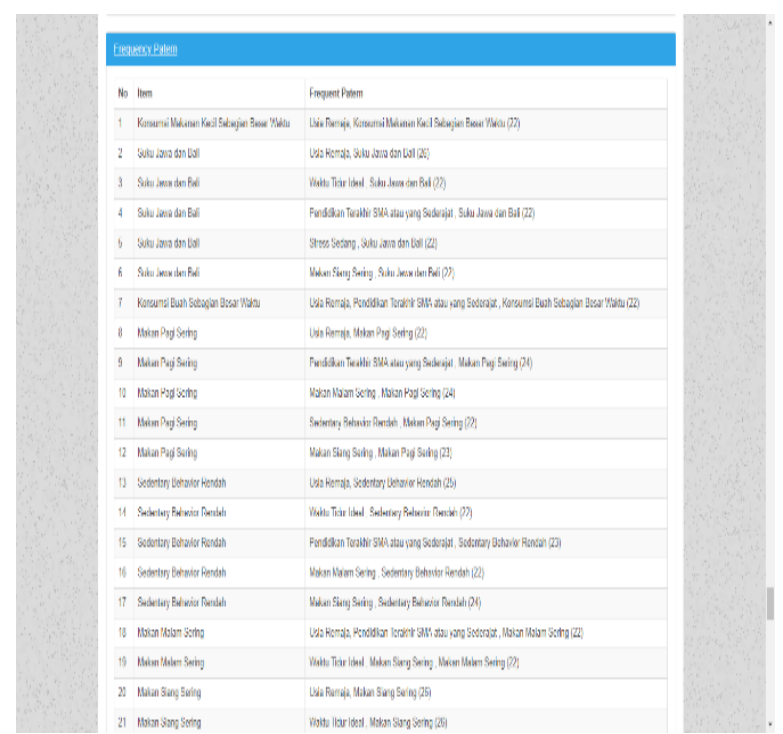

Figure 5 Formation Interface for FP-Growth Stage Frequency Pattern

After getting the rules, then this algorithm starts making Frequency Patterns. Where at this stage you will see several itemsets that are always close together and the number of occurrences is calculated simultaneously. The frequency pattern stage can be seen in Figure 5 above.

5. FP-Growth Calculation Interface Association Rules Stage 


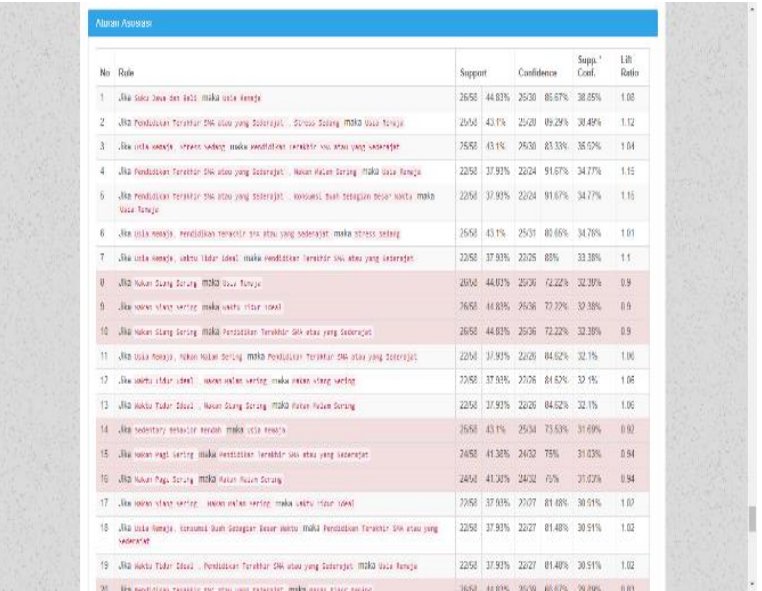

Figure 6 The interface of FP-Growth Calculation of Association Rules Stage

The last step to take is to find association rules that match the predetermined minimum support and minimum confidence. The results of the final association are taken for itemset that has a lift ratio value of more than 1. Figure 6 shows the results of the rules taken, where the itemset that is blocked or colored orange are itemsets that do not meet the requirements.

\section{Results Analysis}

Based on the test results by setting a minimum confidence value of $80 \%$, the following results were obtained:

1. The results of system testing for the male sex group with a very thin BMI category with a minimum support value of 16 , the highest support $\mathrm{x}$ confidence results are $39.56 \%$ in the association rule "If you eat dinner often then ideal sleep time".

2. the results of the system test for the male sex group with the thin BMI category with a minimum support value of 20 , the highest support $x$ confidence results are $55.90 \%$ in the association rules "If the last education is a high school or equivalent, then the adolescent age"

3. the results of system testing for the male sex group with the Normal BMI category with a minimum support value of 20 , the results obtained support $x$ confidence of $70 \%$ in the association rules "If the Age is Adolescent then the Last Education is High School or the Equivalent"

4. the results of the system test for the male sex group with the Fat BMI category with a minimum support value of 22, the highest support $x$ confidence results are $49.23 \%$ on the association rule "If lunch is frequent, then adult age"
5. the results of system testing for the male sex group with the category of BMI Obesity with a minimum support value of 23 , the highest support $\mathrm{x}$ confidence results are $41.34 \%$ in the association rules "If you are a teenager then the last education is high school or equivalent"

6. The results of system testing for the female sex group in the Very Thin BMI category with a minimum support value of 17 , the highest support $x$ confidence results are $41.37 \%$ in the association rule "If Sedentary Behavior is High, then Stress is Moderate"

7. The results of system testing for the female sex group with the Normal BMI category with a minimum support value of 19 , the highest support $x$ confidence results are $37.21 \%$ in the association rule "If you consume milk most of the time then moderate stress"

8. the results of the system testing for the female sex group with the thin BMI category with a minimum support value of 20 , the highest support $x$ confidence results are $68.83 \%$ in the association rules "If the last education is a high school or equivalent, then the teenage age"

9. the results of system testing for the female sex group with the Fat BMI category with a minimum support value of 22 , the highest support $x$ confidence results are $41.65 \%$ in the association rules "If you are an adult then don't smoke"

10. The results of system testing in the female sex group with the BMI category of Obesity with a minimum support value of 24 obtained the highest support x confidence results of $42.91 \%$ in the association rule "If it is ideal sleep time then the adult age"

\section{CONCLUSIONS AND SUGGESTIONS}

\section{Conclusion}

From the 490 calculation data, the results are categorized into 10 , each of which is Men with a Very Thin BMI with the highest support $\mathrm{x}$ confidence value of $39.56 \%$, Men with a Thin BMI of $55.90 \%$, Men with a Normal BMI of $70 \%$, men with a fat BMI of $49.23 \%$, men with an obese BMI of $41.34 \%$, women with a very thin BMI of $41.37 \%$, women with a thin BMI of $37.21 \%$, Normal BMI is $68.83 \%$, women with obese BMI are $41.65 \%$, and women with obese BMI are $42.91 \%$.

\section{Suggestion}

It is necessary to distribute questionnaires more widely to add more data to obtain the results of the association rules which have a higher support $\mathrm{x}$ confidence value in each grouping based on the Gender and Body Mass Index Category. 


\section{REFERENCE}

Anggraeni, S., Iha, M. A., Erawati, W., \& Khairunnas, S. (2019). Analysis of Sales by Using Apriori and FP-Growth at PT. Panca Putra Solusindo. Riset Dan E-Jurnal Manajemen Informatika Komputer, 3(2), 41-46. Retrieved from https://jurnal.polgan.ac.id/index.php/remik/ article/view/10107

Ariati, N. N., Gumala, N. M. Y., \& Nursanyoto, H. (2017). HUBUNGAN KONSUMSI MAKRONUTRIEN DENGAN RESIKO PENUAAN DINI PADA LANSIA YANG MENGIKUTI SENAM LANSIA DI POSYANDU KABUPATEN GANYAR. Jurnal Sangkareang Mataram, 3(3), 34-37. Retrieved from http://untb.ac.id/wp-

content/uploads/2017/06/8.HUBUNGANKONSUMSI-MAKRONUTRIEN-DENGANRESIKO-PENUAAN-DINI-PADA-LANSIANengah-Ariati.pdf

Ayuni, A., Suharso, P., \& Sukidin, S. (2019). PERUBAHAN GAYA HIDUP MAHASISWI UNIVERSITAS ABDURACHMAN SALEH KOTA SITUBONDO (STUDI KASUS: PERILAKU KONSUMTIF MAHASISWI FAKULTAS EKONOMI JURUSAN MANAJEMEN ANGKATAN 2014 DALAM MENGGUNAKAN KOSMETIK BRANDED). JURNAL PENDIDIKAN EKONOMI: Jurnal Ilmiah Ilmu Pendidikan, Ilmu Ekonomi Dan Ilmu Sosial, 13(1), 58-65. https://doi.org/10.19184/jpe.v13i1.10421

Dewi, A., \& Mahmudiono, T. (2013). Hubungan Pola Makan, Aktivitas Fisik, Sikap, dan Pengetahuan Tentang Obesitas dengan Status Gizi Pegawai Negeri Sipil di Kantor Dinas Kesehatan Provinsi Jawa Timur. Jurnal Media Gizi Indonesia, 9(1), 42-48.

Hasanah, D. N., \& Febrianti, M. (2012). KEBIASAAN MAKAN MENJADI SALAH SATU PENYEBAB KEKURANGAN ENERGI KRONIS (KEK) PADA IBU HAMIL DI POLI KEBIDANAN RSI\&A LESTARI CIRENDEU TANGERANG SELATAN. Jurnal Kesehatan Reproduksi, 3(3), 91-104. Retrieved from https://media.neliti.com/media/publications /106703-ID-kebiasaan-makan-menjadisalah-satu-penye.pdf

Jannah, M., \& Utami, T. N. (2018). Faktor yang Memengaruhi Terjadinya Obesitas Pada Anak Sekolah di SDN 1 Sigli Kabupaten Pidie. Jurnal Kesehatan Global, 1(3), 110-118. https://doi.org/10.33085/jkg.v1i3.3928

Kusuma, B. J., \& Pinandita, T. (2011). Rancang Bangun Aplikasi Mobile Perhitungan Indeks Massa Tubuh dan Berat Badan Ideal. Juita, I(4), 157-168. Retrieved from https://www.neliti.com/publications/92701 /rancang-bangun-aplikasi-mobileperhitungan-indeks-massa-tubuh-dan-beratbadan-id

Lestari, Y. D. (2015). Penerapan Data Mining Menggunakan Algoritma Fp-Tree Dan FpGrowth Pada Data Transaksi Penjualan Obat. Seminar Nasional Teknologi Informasi Dan Komunikasi (SNASTIKOM 2015), 60-65. https://doi.org/10.31227/osf.io/t93uv

Mahdali, I. (2019). NUTRITIONAL EDUCATION EFFECTS ON KNOWLEDGE CHANGE, ATTITUDE AND CHANGES IN CONSUMPTION PATTERNS AND OBESITY SEDENTARY ADOLESCENT ACTIVITIES. Universitas Negeri Gorontalo, 1(1), 33-46. Retrieved from http://ejurnal.ung.ac.id/index.php/jjsc/articl e/view/2011

Muliono, R. (2017). Analisis Efisiensi Algoritma Data Mining. Semantika (Seminar Nasional Teknik Informatika), 1(1), 978-602. Retrieved from http://fimi.ua.ac.be/data/.[12]

Nahdiyah, I. (2015). Hubungan antara body image dengan kepuasan hidup pada remaja yang mengalami obesitas di Komunitas KAGUMI (Ikatan Wanita Gemuk Indonesia) (Universitas Islam Negeri Maulana Malik Ibrahim Malang). Universitas Islam Negeri Maulana Malik Ibrahim Malang. Retrieved from http://etheses.uin-malang.ac.id/1531/

Putra, Y. W., \& Solichathi Rizqi, A. (2018). INDEX MASSA TUBUH (IMT) MEMPENGARUHI AKTIVITAS REMAJA PUTRI SMP NEGERI 1 SUMBERLAWANG. Gaster / Jurnal Ilmu Kesehatan, 16(1), 105-115. https://doi.org/10.30787/gaster.v16i1.233

Rahmayanti, D. (2016). Pola Makan Anak Dengan Status Gizi Anak Usia 6-8 Tahun Di SD Wilayah Kelurahan Cempaka. Dunia Keperawatan, 4(1), 8-13. Retrieved from https://ppjp.ulm.ac.id/journal/index.php/JD $\mathrm{K} /$ article/view/2504/

Suryadinata, R. V., \& Sukarno, D. A. (2019). 
PENGARUH AKTIVITAS FISIK TERHADAP RISIKO OBESITAS PADA USIA DEWASA. In The Indonesian Journal of Public Health (Vol. 14).

https://doi.org/10.20473/IJPH.V14I1.2019.1 04-114

Syahputra, D., \& Muhathir, M. (2018). Perhitungan Metode Fuzzy Sugeno Dan Antropometri Dalam Memprediksi Status Gizi Indeks Massa Tubuh. JOURNAL OF INFORMATICS AND TELECOMMUNICATION ENGINEERING, 2(1), 16. https://doi.org/10.31289/jite.v2i1.1676 